\title{
Plant-soil feedbacks in mangrove ecosystems: establishing links between empirical and modelling studies
}

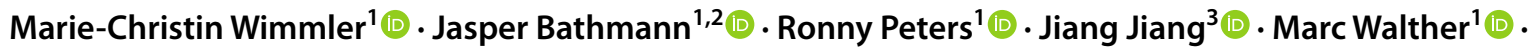 \\ Catherine E. Lovelock ${ }^{4}$ (1) Uta Berger ${ }^{1}$ (1)
}

Received: 28 October 2020 / Accepted: 7 July 2021 / Published online: 22 July 2021

(c) The Author(s) 2021

\begin{abstract}
Key message Plant-soil feedbacks in mangrove ecosystems are important for ecosystem resilience and can be investigated by establishing links between empirical and modelling studies.

Abstract Plant-soil feedbacks are important as they provide valuable insights into ecosystem dynamics and ecosystems stability and resilience against multiple stressors and disturbances, including global climate change. In mangroves, plant-soil feedbacks are important for ecosystem resilience in the face of sea level rise, carbon sequestration, and to support successful ecosystem restoration. Despite the recognition of the importance of plant-soil feedbacks in mangroves, there is limited empirical data available. We reviewed empirical studies from mangrove ecosystems and evaluate numerical models addressing plant-soil feedbacks. The empirical evidence suggests that plant-soil feedbacks strongly influence ecological processes (e.g. seedling recruitment and soil elevation change) and forest structure in mangrove ecosystems. Numerical models, which successfully describe plant-soil feedbacks in mangrove and other ecosystems, can be used in future empirical studies to test mechanistic understanding and project outcomes of environmental change. Moreover, the combination of both, modelling and empirical approaches, can improve mechanistic understanding of plant-soil feedbacks and thereby ecosystem dynamics in mangrove ecosystems. This combination will help to support sustainable coastal management and conservation.
\end{abstract}

Keywords Ecosystem stability $\cdot$ Ecosystem resilience $\cdot$ Ecosystem response $\cdot$ Climate change $\cdot$ Coastal forests $\cdot$ Wetland dynamics

\section{Introduction}

Mangroves are trees and scrubs that form extensive ecosystems that fringe sheltered coastlines, including shallow lagoons, river deltas and estuaries, in the tropics and subtropics. They cover a global area of approximately 137,000

Communicated by M. Buckeridge .

Marie-Christin Wimmler

marie-christin.wimmler@tu-dresden.de

1 Institute of Forest Growth and Forest Computer Sciences, Technische Universität Dresden, 01069 Dresden, Germany

2 Institute of Groundwater Management, Technische Universität Dresden, 01069 Dresden, Germany

3 Department of Soil and Water Conservation, Nanjing Forestry University, Nanjing 210037, China

4 School of Biological Sciences, University of Queensland, St Lucia, QLD 4072, Australia $\mathrm{km}^{2}$ (Spalding et al. 2010) and provide a wide range of ecosystem services (Walters et al. 2008; Barbier et al. 2013). In addition to supporting biodiversity, fisheries and providing other resources for coastal communities, they contribute to regulating water quality, provide coastal protection by reducing erosion and wave energy (Walters et al. 2008; SánchezNúñez et al. 2019), and are important for global carbon sequestration (Donato et al. 2011). Moreover, mangroves help in the maintenance of shorelines during sea level rise through vertical accretion of sediments (Krauss et al. 2014). However, mangrove forests vary in the range and level of ecosystem services that they provide due to variation in their position in the landscape, their species composition and structure (Gleason et al. 2003; Feller et al. 2010), which interacts with both human uses and physical environmental variables.

Despite the importance of mangroves to coastal communities, they are threatened by land-use change and global climate change (Gilman et al. 2008; Alongi 2018). This 
includes anthropogenic interventions, such as the conversion to alternative land-uses (agriculture and aquaculture), overexploitation for timber, and pollution, for example, due to oil spills, sewerage and pesticides (Valiela et al. 1992; Ellison and Farnsworth 1996; Alongi 2018). Threats due to climate change include those associated with extreme drought (Duke et al. 2017), sea level fluctuations (Lovelock et al. 2017), increased frequency of intense storms (Krauss et al. 2009), and sea level rise (Lovelock et al. 2015). To maintain and restore mangroves in the face of this wide range of threats, conservation and restoration strategies could be supported by a profound understanding of mangrove ecosystem development (Lee et al. 2019). Yet, understanding of the mechanisms giving rise to long-term ecosystem development in mangroves is limited (Lugo 1980; Chen et al. 2015).

An emerging paradigm is that mangroves have the capacity to modify their environment through vertical accretion, which has been stimulated by the need to understand the impacts of rising sea levels and other disturbances, (Cahoon and Lynch 1997; Krauss et al. 2014). Additionally, there are observations that mangrove trees can alter the soil pore water salinity through their influence on water uptake and the interplay of salt excretion, salt exclusion and transpiration (Passioura et al. 1992; Lovelock and Feller 2003). However, there are very few research approaches that explicitly address such dynamics (Bathmann et al. 2020; Peters et al. 2020), yet these examples illustrate that mangrove habitat stability and habitat quality are influenced through plant-soil feedbacks, i.e. the interaction between the plant and its surrounding soil, which may be widespread (McKee et al. 2012). An enhanced understanding of mangrove plant-soil feedbacks in the context of ecosystem response to changing environmental conditions is important because plant-soil feedbacks may influence their role in climate change mitigation and adaptation (Mcleod et al. 2011) and the success of restoration and rehabilitation of degraded mangroves ecosystems to regain their ecosystem services (Lewis 2005).

Here, we describe and explore the nature of the plant-soil feedback mechanisms that have been proposed to occur in mangrove ecosystems. In doing so, we aim to gain insights into ecosystem responses to changing environmental conditions, including the potential for rehabilitating habitat degradation and loss as well as enhancing stability and expansion. Additionally, given that the potential to investigate ecosystem development and its responses to disturbances through empirical approaches are limited (e.g. by the time scales of measurements and spatial constraints on laboratory experiments), we assess how numerical modelling has been used as a tool to understand how mangrove ecosystems respond to changing environmental conditions. Specifically, we provide an overview of the theoretical background of feedback mechanisms and ecosystem stability, examine theoretical studies of positive and negative feedback mechanisms, and elaborate on empirical studies that provide evidence of plant-soil feedbacks in mangrove ecosystems. Finally, we list numerical approaches that are applicable to further investigate plant-soil feedbacks, highlighting shortcomings in the current simulation approaches and suggesting potential solutions.

For this literature review, we reviewed the available literature until June 2020 in the data bases 'Web of Science', 'Scopus' and 'Google Scholar', enabling the total timespan (i.e. 1900 - present). First, we searched for empirical studies on plant-soil feedbacks in mangrove ecosystems (keywords listed in SI Table S1). As this search revealed a lack of studies, we additionally searched for specific plant-soil feedback mechanisms based on the feedback components listed by Ehrenfeld et al. (2005). Studies were retained if they describe a plant-soil feedback or a mechanism where either plants alter soil properties or vice versa. Second, we refined the search for models covering the found plant-soil feedbacks in mangroves. For model selection, we focussed on mangrove ecosystems. If no or too few models were found, we stepwise widened the search to coastal wetlands and later terrestrial forests. All models covering the feedback between mangroves and the surrounding soil were selected to be presented here. Non-mangrove models have been classified on their functionality and their popularity (i.e. high citations). Additionally, we aimed to select modelling studies with adaptability to mangrove ecosystems. An overview categorizing all selected studies by their plant-soil feedback is provided in Table 1. As we are interested in providing examples on empirical and numerical plant-soil feedbacks in mangroves, the presented selection provides an overview without the aspiration to be exhaustive.

\section{Feedbacks as drivers for ecosystem dynamics}

The interplay of positive and negative feedbacks is important for characterizing the dynamics of ecosystems and defining the response of ecosystems to changing environmental conditions, including those associated with global climate change (Chapin et al. 2009). Moreover, the effects of changing climate may influence the direction and intensity of plant-soil feedbacks which influences ecosystem behavior and development (Pugnaire et al. 2019).

Feedbacks are defined as the "[...] modification or control of a process or system by its results or effects [...]" (Oxford University Press 2020). For example, in the context of plant-soil interactions, a change in plant community composition may lead to changes in soil conditions, which in turn affects the plant community, and vice versa. 
Table 1 Overview of numerical and empirical studies on plant-soil feedbacks categorized by the soil component the plant interacts with

\begin{tabular}{|c|c|c|c|c|}
\hline \multirow[t]{2}{*}{ Plant interacts with } & \multicolumn{3}{|l|}{ Numerical applications } & \multirow{2}{*}{$\begin{array}{l}\text { Empirical evidence in man- } \\
\text { grove ecosystem } \\
\text { Mangrove forests }\end{array}$} \\
\hline & Terrestrial forests & Coastal wetlands & Mangrove forests & \\
\hline ...Soil elevation & - & $\begin{array}{l}\text { Fagherazzi et al. (2012) } \\
\text { Kirwan and Murray (2007) } \\
\text { Kirwan et al. (2008, 2010, } \\
\text { 2016) } \\
\text { Lago et al. (2010) } \\
\text { Morris et al. (2002) } \\
\text { Mudd et al. (2009) } \\
\text { Rybczyk et al. (1998) } \\
\text { Swanson et al. (2014) }\end{array}$ & $\begin{array}{l}\text { Cahoon et al. }(2002,2003) \\
\text { Morris et al. (2019) }\end{array}$ & $\begin{array}{l}\text { Brunier et al. (2019) } \\
\text { Cahoon et al. (2003) } \\
\text { Hurst et al. (2015) } \\
\text { Huxham et al. (2010) } \\
\text { Lang'at et al. (2014) } \\
\text { Lovelock et al. (2017) } \\
\text { Mazda et al. (2002) } \\
\text { McKee (2011) } \\
\text { McKee et al. (2007) } \\
\text { Rogers et al. (2019) }\end{array}$ \\
\hline ... Porewater salinity & $\begin{array}{l}\text { Chen et al. (2004) } \\
\text { Janssen et al. (2008) } \\
\text { Rietkerk \& Koppel (1997) }\end{array}$ & $\begin{array}{l}\text { Liu et al. (2019) } \\
\text { Teh et al. (2015) } \\
\text { Wang et al. (2007) } \\
\text { Zhang et al. (2018) }\end{array}$ & $\begin{array}{l}\text { Bathmann et al. (2020) } \\
\text { Peters et al. (2014) } \\
\text { Sternberg et al. (2007) } \\
\text { Teh et al. (2008, 2013) }\end{array}$ & $\begin{array}{l}\text { Ball (1988) } \\
\text { Ball \& Pidsley (1995) } \\
\text { Cintron et al. (1978) } \\
\text { Clough (1984) } \\
\text { Hao et al. (2009) } \\
\text { Lin et al. (1992) } \\
\text { Naidoo (2006) } \\
\text { Sherman et al. (2003) }\end{array}$ \\
\hline $\begin{array}{l}\text {. Chemical and } \\
\text { biochemical soil } \\
\text { components }\end{array}$ & $\begin{array}{l}\text { Bever et al. (1997) } \\
\text { Gbondo-Tugbawa et al. } \\
\quad(2001) \\
\text { Herbert et al. (1999) } \\
\text { Miki and Kondoh (2002) } \\
\text { Miki et al. (2010) } \\
\text { Rietkerk and Koppel (1997) } \\
\text { Xiao et al. (2019) }\end{array}$ & Swanson et al. (2014) & $\begin{array}{l}\text { Akamatsu and Ikeda (2016) } \\
\text { Chen \& Twilley }(1999) \\
\text { Grueters et al. }(2014,2019)\end{array}$ & $\begin{array}{l}\text { Feller (1995) } \\
\text { Feller et al. (2003, 2009) } \\
\text { Liu et al. (2014) } \\
\text { Lovelock and Feller (2003) } \\
\text { Lovelock et al. (2004, 2009) } \\
\text { McKee (1993) } \\
\text { Naidoo (2006) } \\
\text { Nickerson and Thibodeau } \\
\quad(1985) \\
\text { Sherman et al. (1998) }\end{array}$ \\
\hline
\end{tabular}

The numerical studies are additionally classified by the ecosystem type (terrestrial, coastal wetland or mangrove)

Most feedbacks are directional. Their sign, i.e. direction is defined by the nature of the feedback mechanism itself, which is either self-decreasing (negative feedback, Fig. 1a) or self-amplifying (positive feedback, Fig. 1b) (Ramaprasad 1983). Since negative feedbacks tend to

a

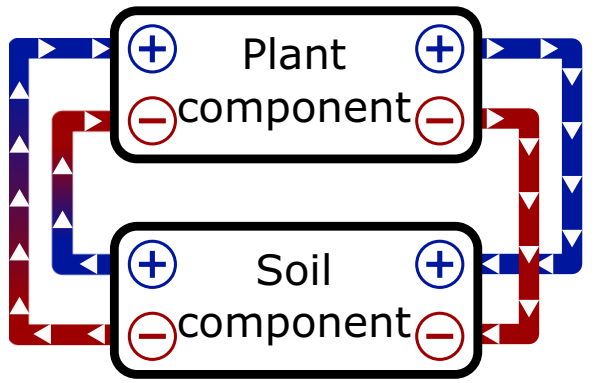

Fig. 1 Illustration for feedback types: a Increase in one plant component leads to increase in a soil component, which in turn decreases the plant component. This decreased plant component, in turn, leads to a reduction in the soil component (e.g. Fig. 3b-d). Thus, the negative feedback loop is stabilizing the system parameters. b In a counteract perturbations, their presence in loop processes is required to stabilize an ecosystem in the presence of environmental noise (Zeng and Wang 2012). In contrast, positive feedbacks amplify or enhance changes that might move away a system from its dynamic equilibrium, destabilizing b

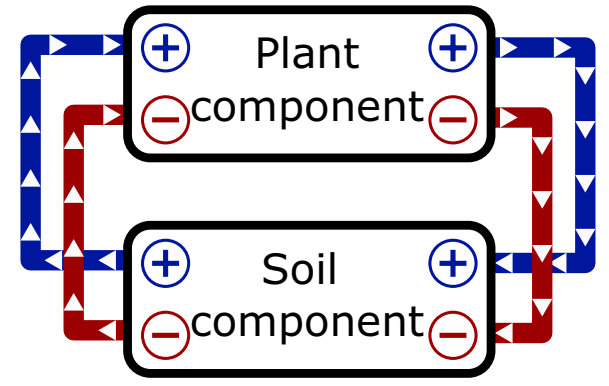

dynamic ecosystem state, an increase of a plant component increases the corresponding soil component, which facilitates further increase of the plant component. This positive feedback eventually leads to ecosystem state change (e.g. Fig. 3a) 
it which eventually may lead to state shifts (Suding et al. 2004). However, as multiple feedback processes can coexist, not only the presence of feedbacks but also their respective dominance are decisive for the direction. Overall, feedback strength specifies the importance of a feedback relative to other dynamic factors in the ecosystem (Ehrenfeld et al. 2005).

The processes behind plant-soil feedbacks take place on various temporal and spatial scales (e.g. for mangrove see Feller et al. 2010), which can be categorized as short (hoursdays, individual plant), intermediate (years to decades, plant population), or long (centuries to millennia, landscape). The number of components and interactions involved define the complexity of a particular feedback (Ehrenfeld et al. 2005).

As negative feedbacks tend to stabilize and positive feedbacks tend to destabilize ecosystem states, their interplay defines the ecosystem dynamics. The existence and implications of alternative quasi-steady states due to positive feedbacks in ecosystems have been well studied in the past (May
1977; Noy-Meir 1975). An ecosystem state is classified as either (i) a dynamic, rapidly changing state, where the individual components or the distribution of components of a system may change, or (ii) a quasi-steady state, where the average properties of components or the distribution of components remain relatively constant over time (Fig. 2). Additionally, various theoretical studies on the transition between alternative quasi-steady states show that state changes are a consequence of positive feedbacks (Scheffer et al. 2001; Scheffer and Carpenter 2003; Rietkerk et al. 2004). Assuming the maintenance of ecosystems in quasi-steady states are dominated by negative feedbacks, then after a disturbance, the system should return to a quasi-steady state configuration, which may be similar to or different from the configuration before the disturbance, depending on the direction and intensity of the feedbacks. Additionally, before reaching the quasi-steady state, the system's properties may be highly dynamic (Scheffer et al. 2009). In the quasi-steady state, the system or its components are providing sufficient levels of

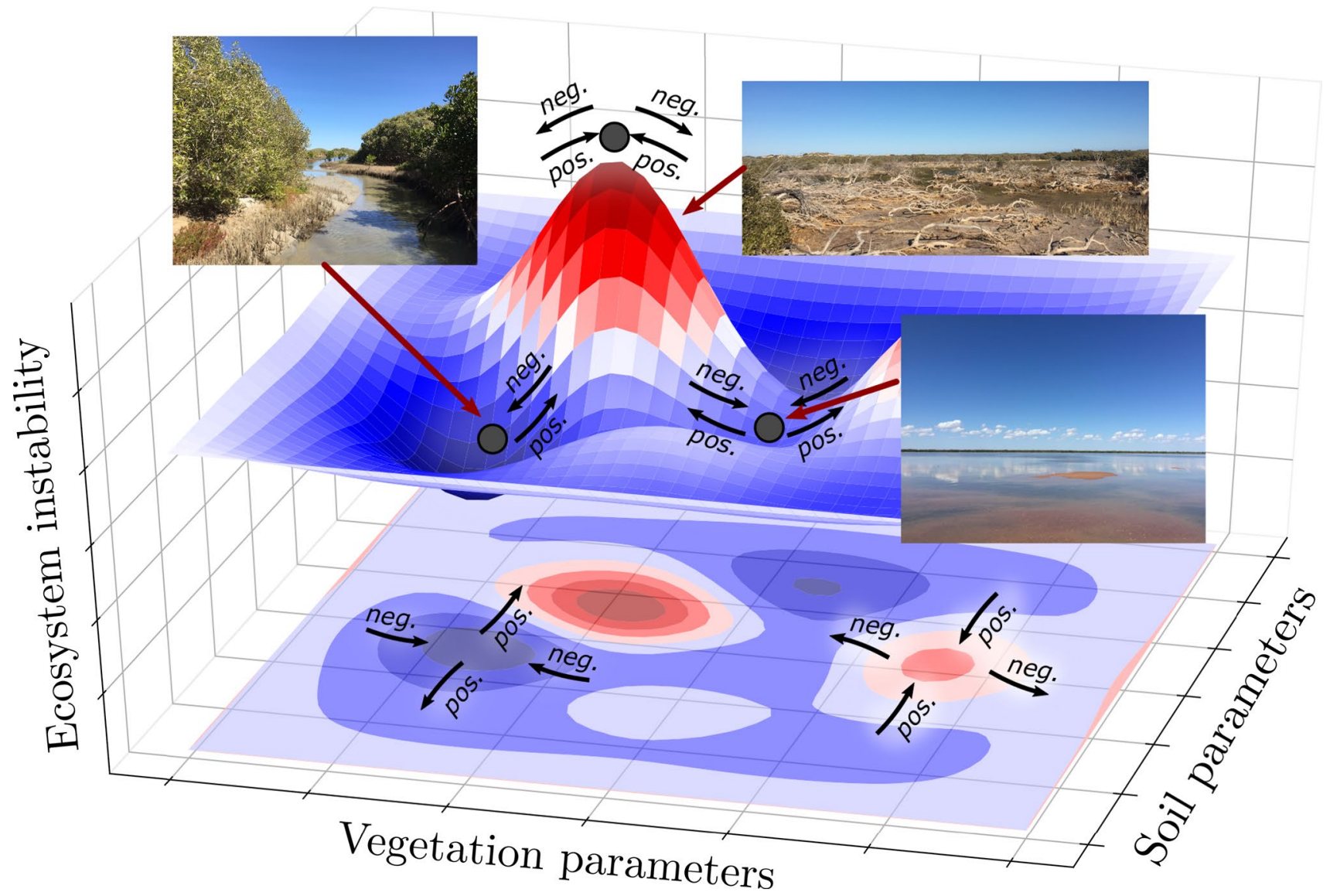

Fig. 2 Illustration of the role of positive and negative feedbacks for ecosystem stability: for each set of soil- and vegetation parameters, the ecosystem stability can be estimated. Negative feedbacks tend to change the parameter set until the system reaches a more stable state, whereas positive feedbacks do the opposite. The valleys in the poten- tial landscape (blue areas) correspond to steady ecosystem configurations. The photographs illustrate mangrove ecosystems in different states, i.e. closed canopy, transitioning and salt flat (left to right), in arid zone mangroves of Northwest Australia 
buffering or are able to adapt to perturbations rapidly enough to maintain system properties. The dynamic state, on the other hand, is the result of the intensity of all positive feedbacks and environmental noises overcoming the stabilizing effects of apparent negative feedbacks. Consequently, there is a direct link between the direction and intensity of feedbacks and the transitions between ecosystem states.

Scheffer and Carpenter (2003) highlighted that positive feedbacks are responsible for regime shifts in ecosystems. Over long temporal scales, where the intensity of all feedback effects is destabilizing, the system should eventually merge into a new quasi-steady state (Scheffer et al. 2009). The process is illustrated in Fig. 2: System instability defines a hyperplane within the parameter space, which can be interpreted as a potential landscape. Overall, positive feedbacks can drive the system out of one potential "well" (ecosystem state) into another. For example, extreme drought and altered inundation regimes can result in death of mangroves (Fig. 2). Within the new potential "well", the intensity of all feedback effects becomes stabilizing, e.g. seedling recruitment is inhibited by high levels of evaporation, highly saline conditions and lack of shade. The resulting changes in the environment can be less favourable for individuals of particular species (e.g. mangrove trees compared to cyanobacteria), but may stabilize the ecosystem in another configuration than before the transition (reduced mangrove cover and conditions on salt flats inhibit mangrove recruitment). At this point, negative feedbacks can prevent particular species from outcompeting all others, ultimately avoiding another system change. This in turn increases resilience for the whole ecosystem and provides stability against the effects of external perturbations and stressors (e.g. cyclones, flooding). However, the result of external perturbations and changes in environmental conditions (e.g. climate change effects) may not necessarily lead to a full transition, but might result in changes in habitat characteristics (e.g. scrub mangrove compared to taller mangroves).

An understanding of the nature of feedbacks is therefore crucial to predict the development of ecosystems in the face of climate change. In the past, analyses of feedbacks have identified early warning signals for regime shifts in other ecosystems. Identified early warning signals are, for example, changes in the variability, autocorrelation and recovery times in the response of ecosystems to small perturbations (Rietkerk and van de Koppel 2008; Scheffer et al. 2009; Carpenter et al. 2011). Scheffer et al. (2009) developed a theoretical framework to identify the nature of changes in feedbacks as they approached tipping points. These tipping points are critical turning points, where ecosystems change their states abruptly from one state (e.g. mangrove trees) to another (e.g. salt flat). This theoretical framework was corroborated by Carpenter et al. (2011) with empirical evidence obtained from experimental manipulation of an aquatic food web, which was destabilized by the addition of top predators to a lake over a 3-year period. The warning signals included nonlinear dynamics of zooplankton biomass. For mangrove ecosystems, such an empirical validation of the connection between feedbacks and regime shifts has not yet emerged, but the identification of feedback mechanisms and their understanding is a first step to predicting potential ecosystem state changes. Mangrove state changes of interest include those from mangroves to open water or tidal flats (Asbridge et al. 2019), or from saltmarsh or mud flats to mangrove (e.g. Whitt et al. 2020), or from high diversity mangrove to low diversity ecosystems (Polidoro et al. 2010).

The identification of plant-soil feedbacks in mangrove ecosystems is challenging. Past research on plant-soil interactions was conducted in artificial environments focussed on terrestrial forest species (Putten et al. 2016; De Long et al. 2019). In these studies, the performance of plants growing in their own soil is compared to growth in foreign soil, where their own and foreign soils are defined as soils cultured by the target species or another species, respectively (Pernilla Brinkman et al. 2010). During these experiments, abiotic drivers (De Long et al. 2019) and ecological factors (Ehrenfeld et al. 2005) are removed (or controlled), such that the transfer of findings to the field is challenging. Furthermore, different experimental designs and their statistical analysis to determine the direction and the strength of plant-soil feedbacks differ widely, leading to different interpretations of feedbacks and that studies are essentially not comparable (Pernilla Brinkman et al. 2010). Additionally, feedbacks may act over large spatial and temporal scales (Ehrenfeld et al. 2005), exceeding experimental capacities as well as usual project funding.

In general, it has been suggested that stressful environments have more facilitative interactions among components of ecosystems than competitive ones (Ehrenfeld et al. 2005; Halpern et al. 2007) and that these may underpin a range of stabilizing plant-soil feedbacks. The observation that particular species or groups of species can shape wetland topography to maintain favourable environments for themselves (Silvestri et al. 2005; D'Alpaos et al. 2012; Jiang and DeAngelis 2013) provides evidence that stabilizing feedbacks are important in maintaining coastal wetland communities. In mangrove and other wetland ecosystems, there are high levels of interest in increasing the effectiveness of restoration, for example with the use of facultative "foundation plants" (Yando et al. 2019; Renzi et al. 2019) and thus the exploration of plant-soil feedbacks is both theoretically interesting and of practical importance.

We conclude that the understanding of plant-soil feedbacks provides insights into ecosystem response to their environment. Below we consider plant-soil feedbacks in mangrove ecosystems. We explore how analysis of feedbacks in mangroves can be used to predict ecosystem 
responses to different disturbances and aid in developing strategies to manage the effects of disturbances and global climate change.

\section{Plant-soil feedbacks in mangroves and applications of numerical modelling}

We categorized plant-soil feedbacks in mangroves that are described in the literature as feedbacks between mangrove vegetation and (i) soil elevation, (ii) porewater salinity, or (iii) chemical and biochemical components of the soil. Many of the studies we examined included added complexities due to a wide range of interacting factors (e.g. bioturbation by burrowing animals). However, we focus on examples of feedbacks involving one soil compartment or property (e.g. porewater salinity), rather than a combination of multiple factors (Fig. 3). Where possible, we link the described plant-soil feedback to modelling approaches that have been applied to mangrove ecosystems, or link to appropriate approaches applied to other coastal wetlands or terrestrial habitats. An overview of the studies that have considered plant-soil feedbacks in mangroves, either empirical or modelling studies can be found in Table 1 .

\section{Mangrove vegetation and soil elevation}

\section{Empirical evidence}

Changes in soil surface elevation have been investigated widely in mangroves (e.g. Sasmito et al. 2016 and references within). At the surface of the soil, accretion due to sedimentation and accumulation of organic matter are often the main drivers for elevation change, whereas root growth and decomposition make important contributions to subsurface changes in soil elevation (Fig. 3a; Cahoon et al. 2006;
McKee 2011). Variation in soil surface elevation relative to sea level alters the frequency, depth and duration of inundation which influences nutrient and oxygen availability and other soil biogeochemical processes and therefore the growth and composition of the plant community (Twilley et al. 2019).

This process of surface elevation gain in mangroves can stabilize the mangrove ecosystem (negative feedback) as exemplified in Belize and in southwest Florida, where vertical accretion, mainly by root and leaf litter inputs, resulted in less frequently inundated soils (McKee 2011). Growth reduction and partial tree mortality, in turn, reduced surface elevation through decomposition of dead roots and sediment compaction (Lang'at et al. 2014). As a result, the frequency and duration of flooding can increase again which favour tree growth, thereby maintaining a stabilizing feedback loop (Woodroffe et al. 2016).

Mass mangrove tree mortality occurred in Honduras after Hurricane Mitch (Cahoon et al. 2003). In this case, positive feedback loops were observed where the loss in soil elevation due to peat collapse prevented the re-establishment of the same species and favoured the recruitment and growth of other mangrove species (Cahoon et al. 2003). The overall loss of mangrove cover can also lead to transitions to alternative ecosystem states, possibly through reducing suitability for recruitment (Balke et al. 2014; Hurst et al. 2015). Additionally, loss of mangrove cover enhances erosion, which can lead to a further decline in soil elevation (Mazda et al. 2002) and shoreline retreat (Brunier et al. 2019) where mangroves are replaced by mud flats.

Plant-soil feedbacks are also apparent over long time scales (centuries to thousands of years). Correlations of mangrove accretion rates with local mean sea-level rise suggest that mangroves kept pace with sea level rise for periods of the Holocene (Alongi 2008, 2015), which led to the development of large deposits of sediment carbon from mangrove

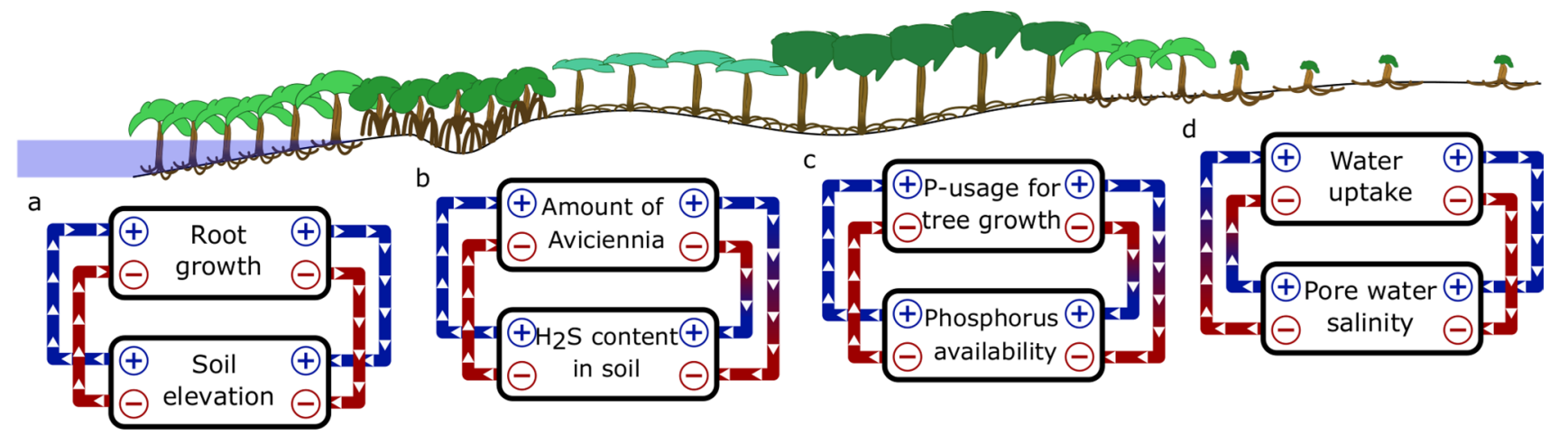

Fig. 3 Schematic representation of a mangrove transect with emerging zonation patterns parallel to the shoreline. Different colours represent different species. The transition between clusters of similar trees provides evidence for underlying plant-soil feedback. Position of the feedbacks in the intertidal cross section of the diagram does not imply that a particular plant-soil feedback is restricted to that position in the intertidal zone. Red and blue colours in the respective plant or soil component represent negative and positive increments, respectively 
production (Rogers et al. 2019). However, sediment cores also revealed a decline in mangrove forests with sea level rise that exceeds 6-7 mm/year (Saintilan et al. 2020), unless they can migrate unimpeded onto coastal floodplains (Schuerch et al. 2018), suggesting positive feedbacks occur. The stability of feedback mechanisms, and thus the ability of mangroves to withstand sea level rise, also depends on site-specific conditions that contribute to soil surface elevation change. Sites factors that can influence the intensity and direction of plant-soil feedbacks include flooding intensity (influenced by subsidence associated with geological isostatic adjustments and extraction of oil, gas and water on coastal floodplains), geomorphology, storm frequency, sediment supply, groundwater and nutrients inputs and species composition (Gilman et al. 2008; Krauss et al. 2014; Lovelock et al. 2015; Sasmito et al. 2016). At Twin Cays (Belize), for example, root production is a major factor contributing to elevation change where interior flooded zones with scrub trees have five times lower accretion rates than fringe zones and are therefore more vulnerable to sea level rise (McKee et al. 2007). Both positive and negative plant-soil feedbacks are likely to contribute to the response of mangrove vegetation to climate change, although the relative importance of plant-soil feedbacks and their interactions with climate change factors and human modification of the coastal zone to the overall outcome is yet to be assessed.

\section{Modelling approaches}

The models reviewed here have not focussed on plant-soil interactions but have mainly been developed to investigate two objectives: (i) the ecosystem response of coastal wetland vegetation to rising sea levels (e.g. Rybczyk et al. 1998; Morris et al. 2002), and (ii) the spatiotemporal evolution of vegetation and surface topography patterns (e.g. Kirwan and Murray 2007). Predictive models of how coastal wetland ecosystems respond to sea level rise usually include the definition of drivers that describe changes in the modelled system components. Drivers for relative soil elevation changes are often categorized as either from abiotic- and biotic contributions (Fig. 4a). Examples of abiotic contributions are sediment erosion and deposition, whereas biological processes are exemplified by the production of organic matter by roots or the decomposition of leaf litter or peat.

For example, the influence of organic decomposition on relative elevation changes has been conceptualized using the coastal-wetland model of Rybczyk et al. (1998). The model was successfully applied in mangrove ecosystems, establishing the connection between peat collapse and mass tree mortality after Hurricane Mitch on the islands of Guanaja and Roatan, Honduras (Cahoon et al. 2002, 2003).

In 2007, a model to study the spatiotemporal development of tidal marsh platforms and the interwoven channel networks was introduced Kirwan and Murray (2007). The processes of sediment transport and the deposition and erosion of sediments were described in detail, which indicated there were threshold levels of sediment supply that supported the maintenance of marshes with sea level rise. This model considers the contribution of sediment trapping induced by the vegetation but omitted the contribution of other biomass-related processes (e.g. decomposition) to soil surface elevation change which was added later to the model as described below.

Models that considered both the abiotic and the biotic contributions to surface elevation dynamics in coastal wetlands have been developed. In 2002, a conceptual model of marsh elevation change (Marsh Equilibrium Model, MEM) was introduced and validated with field data from Goat Island (USA) (Morris et al. 2002) and which has subsequently been modified for mangroves (Morris et al. 2019). Further modelling work studied marsh stratigraphic response to sediment supply and the rate of sea-level rise (Mudd et al. 2009), the development of wetland topography (Lago et al. 2010), wetland ecosystem resilience to sea level rise (Swanson et al. 2014), and the development of marsh size in response to rising sea level (Kirwan et al. 2016).

Although these models partly rely on empirical relationships (Kirwan et al. 2010), they were able to show that the models qualitatively aligned in predicting the necessary conditions for marsh ecosystems to survive predicted rates of sea level rise. Most of the models above have not been explicitly applied to mangrove ecosystems. However, since the vegetation's response to variations in mean water depth is modelled as empirical relationships (Fig. 4a), a parametrization of the models for different mangrove ecosystems is possible (e.g. Morris et al. 2019).

\section{Mangrove vegetation and porewater salinity}

\section{Empirical evidence}

Observed patterns in species distribution and structure along salinity gradients provide evidence for feedbacks between porewater salinity and mangrove trees (Fig. 3d). Mangroves must exclude most of the salt in the porewater of the root zone from their transpiration stream to avoid the toxic effects of $\mathrm{NaCl}$ on metabolic components (Ball 1988). By excluding salt during their water uptake, mangroves salinize the surrounding soil (Passioura et al. 1992). With increasing soil salinity, photosynthetic rates and thus growth rates decline (Ball 1988). Prediction suggests that by salinizing the soil, trees may eventually limit water uptake and so soil salinity stabilize (Bathmann et al. 2020).

Mangroves in their scrub form are adapted to high salinities and they have higher root to shoot ratios than taller trees (Ball 1988; Hao et al. 2009). The water use efficiency 


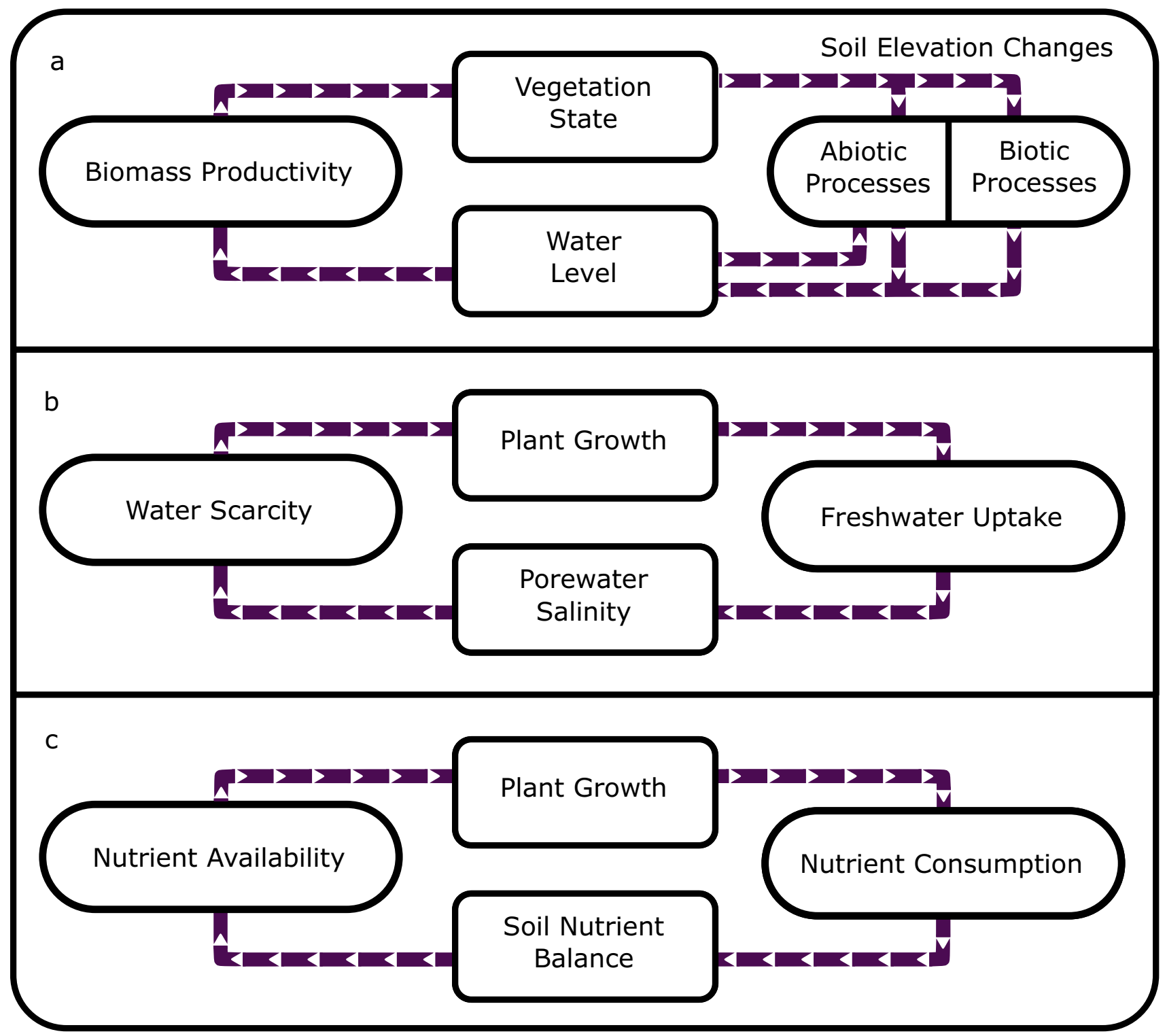

Fig. 4 A simplified schematic representation of modelled feedbacks between a vegetation and tidal water levels, $\mathbf{b}$ plant growth and soil water salinity, and c) plant growth and soil nutrient balance. The coupling of biomass production and soil parameters are often described

of scrub trees is higher than in taller mangroves (Lin et al. 1992), and their impact on porewater salinity is also smaller due to their lower water uptake. Therefore, the persistence of scrub (or dwarf) forms observed on the landward fringe of mangrove forests where hypersalinity ( $>35 \mathrm{ppt}$ ) occurs due to limited tidal inundation and evapotranspiration, could be partially explained by a negative feedback between porewater salinity and tree growth (Fig. 3d, Naidoo (2006)).

However, from the perspective of inter-specific competition, the plant-porewater salinity feedback can be positive. Although mangroves tend to grow rapidly at about $25 \%$ seawater (Clough 1984), species vary in their range of with state variables that characterise the condition of the respective compartments. The direction of the arrows indicates which process (or status) influences which status (or process)

salt tolerance (Ball and Pidsley 1995). Hence, a more salttolerant species can outcompete a less tolerant species by driving porewater salinity higher (withdrawing more water) and thereby its growth can be maintained at the expense of less salt-tolerant neighbouring species, although effects of canopy shading may also influence biomass and competitive outcomes (Kirui et al. 2012). If the soil salinity exceeds the maximum for mangrove growth high in the intertidal zone, halophytic herbaceous species or cyanobacterial mats eventually replace mangroves (Cintron et al. 1978; Duke et al. 1998). 


\section{Modelling approaches}

Numerical models that investigate feedback mechanisms between vegetation and porewater salinity in mangrove ecosystems can be categorized by the spatial scale of the model and the level of detail incorporated within the models. There are regional models (Zhang et al. 2018; Liu et al. 2019), site-specific models (Sternberg et al. 2007; Teh et al. 2008, 2013, 2015) and models which describe the interactions on the scale of individual plants (Bathmann et al. 2020). Different scales of the models tend to incorporate different levels of detail. For example, at large scales, course-grained hydrological model tend to have no plant-specific details, mesoscale models often incorporate coarse-grained plant responses, while at small spatial scales high levels of detail can be included. For example, the fine-scale model of Bathmann et al. (2020) focusses on the plant's freshwater uptake, while the models of Liu et al. (2019) and Teh et al. (2015) focus on water scarcity in the soil (Fig. 4b).

The regional models of vegetation-porewater salinity feedbacks do not explicitly explore plant water use, but are used to predict the dynamics of porewater salinities on regional scales. This can help to understand the impacts of regional changes in water availability, which are predicted to vary as a consequence of climate change on ecosystem processes. For example, Zhang et al. (2018) used a detailed hydrological model to connect hydrological processes on the surface and the subsurface to inform how hydrological regimes in coastal wetlands influence the energy budgets and evapotranspiration of vegetated patches. The model developed by Liu et al. (2019) extended this idea through the incorporation of abiotic transport and accumulation processes to understand the dynamics of porewater salinity within the soil of coastal wetlands.

Site-specific models investigate the response of ecosystems within sites to changing environmental conditions. The Variable Water Table Salinity (VWTS) model coupled the transpiration rates of mangroves to variation in porewater salinity (Sternberg et al. 2007). Starting from a simplified model for both vegetation and soil water dynamics, the VWTS model has been extended to include horizontal diffusion of porewater (Teh et al. 2008). This idea was further developed by replacing this continuous vegetation model with an individual-based plant model, which was coupled with the United States Geological Survey groundwater model SUTRA (saturated-unsaturated transport), which describes the porewater salinity dynamics in a mechanistic manner (Teh et al. 2013). The resultant mangrove transport model (MANTRA) has been successfully applied to predict patterns of coastal vegetation zonation (patches of freshwater hammocks and mangrove trees) in the Everglades (Florida) caused by variation in porewater salinity resulting from sea level rise and storm surges (Teh et al. 2015).
Further improvements in the explicit incorporation of mangrove-porewater salinity feedbacks have been made through the introduction of a mechanistic feedback model (MANGA, Bathmann et al. 2020). MANGA coupled a process-based flow and transport groundwater model, which described porewater salinity changes (OpenGeoSys Version 6, www.opengeosys.org) to an individual-based mangrove model (BETTINA, Peters et al. 2014)) that incorporates plant water use. This coupled model suggested that plant-soil feedbacks contribute to maintaining mangrove tree forms (scrub vs. taller) and species zonation patterns (Bathmann et al. 2020, 2021).

\section{Mangrove vegetation and the biogeochemistry of soils}

\section{Empirical evidence}

There is evidence that altered nutrient levels and forms of nutrients can cause both negative and positive feedbacks on mangrove vegetation, as has been widely observed in terrestrial forests (Tilman 1987; Vitousek et al. 1997). Fertilization of mangroves with nutrients can have strong positive effects on their growth (Fig. 3c; Lovelock et al. 2004; Feller et al. 2009). In Belize, a gradient in nutrient availability from the seaward edge to inland parts of a mangrove island were observed, where nitrogen $(\mathrm{N})$ limitations on growth tended to occur near the shoreline while in scrub mangroves in the landward position phosphorus (P) limited tree growth (Feller et al. 2003). In this case, a negative feedback loop maintains the small $(<2 \mathrm{~m}$ tall) scrub form of these trees as available $\mathrm{P}$ is taken up and used for growth by fringing trees, which reduces $P$ availability in soils which further feedbacks on growth (Feller 1995). Similar patterns of nutrient-limited scrub forests have been widely observed (Naidoo 2006; Feller et al. 2009; Lovelock et al. 2009) as well as differential sensitivity of mangrove species to nutrient availability (Lovelock and Feller 2003), which suggests widespread negative feedbacks that may influence the structure of mangroves and species composition. The addition of nutrients, either through human influences (Valiela et al. 1992; Valiela and Cole 2002), deposition during storms (Smoak et al. 2013) or through species-specific litter production and composition rates (Sherman et al. 1998; Liu et al. 2014) can alter the strength or direction of these feedbacks.

Microbial processes in soils can also contribute to plant-soil feedbacks. A "semi-cyclic succession" of Rhizophora mangle and Avicennia germinans has been hypothesized due to differences in species tolerance to hydrogen sulphide $\left(\mathrm{H}_{2} \mathrm{~S}\right)$, a natural phytotoxin that is produced by bacteria under anoxic soil conditions (Fig. 3b; Nickerson and Thibodeau 1985; McKee 1993). Although sulphide concentrations measured within the root systems of both 
species were low, the concentration of $\mathrm{H}_{2} \mathrm{~S}$ in the surrounding unvegetated soil was approximately five times higher for A. germinans than in R. mangle, and thus Nickerson and Thibodeau (1985) hypothesized that $A$. germinans releases oxygen from its roots which oxidizes the surrounding soil, thereby removing $\mathrm{H}_{2} \mathrm{~S}$. As a result of this feedback, A. germinans can grow in areas with higher $\mathrm{H}_{2} \mathrm{~S}$ gas concentration but in doing so, they lower the concentration of $\mathrm{H}_{2} \mathrm{~S}$ in the soil. Consequently, as trees of A. germinans are established, the environmental conditions become more suitable for the establishment and growth of $R$. mangle.

\section{Modelling approaches}

Despite the empirical evidence of mangrove-soil biogeochemical feedbacks, the available models for vegetationnutrient dynamics in mangrove ecosystems are limited. We therefore first discuss models that describe nutrient dynamics within mangrove soils (Fig. 4c, "Nutrient Consumption"). Secondly, models describing the effect of nutrient availability on mangrove plant growth are presented (Fig. 4c, "Nutrient Availability"). Finally, we discuss modelling approaches from the terrestrial ecosystem, where full feedback loops have been described (Fig. 4c).

In the late 1990s, Chen and Twilley (1999) developed the NUMAN (Nutrient in Mangroves) model which describes the nitrogen and phosphorus balance in a $60-\mathrm{cm}$-deep soil profile of mangrove ecosystems, but which does not include the effect of changing nutrient availability on plant growth. This model was used to describe the mechanisms that resulted in the observed accumulation of carbon and nutrient in mangrove soils along gradients of mangrove productivity. Recently, more detailed nutrient dynamic models have been developed that incorporated the coupling of groundwater flow and nutrient cycling (movement) in mangroves (Akamatsu and Ikeda 2016). While these models described the apparent development of nutrient and carbon concentrations within the soil, the explicit description of a feedback mechanism affecting mangrove growth was not included.

The individual-based mangrove forest model, mesoFON, considered the implications of nutrient availability within soils on mangrove growth dynamics (Grueters et al. 2014). In 2019, this model was calibrated and successfully parametrized for Rhizophora apiculata in Malaysia (Grueters et al. 2019). Although an effect of the available nutrients on tree growth was described within mesoFON, the description of the potential feedback of the plants' nutrient use on the soil nutrient balance was not included. However, the authors emphasized the importance of explicitly considering the interplay (i.e. feedbacks) between mangrove growth models and other biochemical processes within the ecosystem.

Some models of plant-soil feedbacks in terrestrial ecosystems are particularly relevant for application to modelling plant-soil feedbacks in mangrove ecosystems. The multielement limitation model (MEL) couples biomass production rates to nitrogen availability in forests (Herbert et al. 1999) and could be adapted for use in mangrove ecosystems. A model that included the effects of the different microbial communities on the decomposition of leaf litter, nutrient availability and its subsequent effects on plant growth and plant community composition was developed by Miki and Kondoh (2002). Differences in communities of microbial decomposers and their effects on rates of plant litter decomposition have been added to this model further enhancing the detailed mechanisms by which microbial communities influence nutrient availability (Miki et al. 2010). Using this model, the authors were able to show the importance of microbial communities on plant-soil nutrient feedbacks. Another approach, which includes different vegetation types as well as microbial communities, suggested a mathematical framework to connect plant-soil nutrient feedbacks to competition among plant species (Bever et al. 1997). Bever et al.'s model has been further extended by a factor that describes interspecific plant-soil nutrient feedbacks (Xiao et al. 2019). Through the development of this detailed model, these authors were able to show the emergence of communities of different plant species compositions, which depended on the soil microbial communities. These terrestrial models for plant-soil feedbacks only account for a small amount of the studies available in the literature, but they provide an indication of the wide range of different plant-soil feedback models and their usability for further investigating plant-soil feedbacks in mangrove ecosystems in response to changing environmental conditions.

\section{Implications for ecosystem resilience}

Mangroves are threatened by a range of climate change effects and anthropogenic interventions (Friess et al. 2019) and therefore require management, including those focussed on conservation and restoration (Lewis et al. 2016). As these changes affect both, the composition of plant and soil communities (Pugnaire et al. 2019), the study of plant-soil feedback mechanisms and their relation to ecosystem stability may provide the means to explore tipping points in state transitions of mangroves and other coastal wetlands, even if empirical detection of tipping points is unlikely (Hillebrand et al. 2020).

There is evidence that plant-soil feedbacks shape mangrove ecosystems in both empirical and numerical studies. Knowledge of feedbacks is particularly developed and useful for understanding mangrove resilience in the face of sea level rise, which is of major global concern. Detailed descriptions of surface and subsurface processes involved in surface elevation changes are available for a wide range of 
sites (Lovelock et al. 2015), and theoretical outlines of the mechanisms involved in the feedback process of soil elevation changes in mangroves as a response to changing sea level are also available (McIvor et al. 2013). The development of models based on those for saltmarshes (e.g. Morris et al. 2002) that explicitly incorporate plant-soil feedbacks could be used to explore changes in variability, levels of autocorrelation among parameters and recovery times from small-scale disturbances with increasing rates of sea level rise, as they approach the proposed $\sim 7 \mathrm{~mm} /$ year threshold (Saintilan et al. 2020). Assessing indicators of ecosystem transitions with sea level rise could help to build understandings of the processes operating prior to mangrove loss.

Incorporating plant-soil feedbacks associated with nutrient and carbon cycling within mangrove models could result in increases in understanding mangroves' role in carbon sequestration (blue carbon) and nutrient retention as well as the consequences of anthropogenic changes. Despite early progress in this field (Chen and Twilley 1999) and growing empirical data, models that incorporate plant-soil biogeochemical feedbacks are limited in their development and application, which given the growing knowledge of the role of mangroves to climate change mitigation (Mcleod et al. 2011) is a clear knowledge gap.

The proposed plant-soil porewater salinity and biogeochemistry feedbacks that we have examined (above) may interact with other environmental factors that could limit the strength of the feedbacks, which could be further explored using models. For example, hydrological processes may superimpose or reinforce single feedbacks in mangrove ecosystems. The strength of the interaction between porewater salinity and plant growth, for example, may be strongly influenced by the hydrological regime as nutrient delivery is altered or salt is diluted and leached (Hayes et al. 2019). The interplay of hydroperiod regime, salinity and vegetation has been observed in Colombia where the construction of a road led to the disturbance of the natural hydrological system (Röderstein et al. 2014): the reduced freshwater inflow led to a higher salinity and thus to a decline in mangrove cover. However, after the hydrological connection was restored, mangrove vegetation recovered. A process-based model built from such a priori knowledge (e.g. from existing empirical observations) would allow to test a variety of hypotheses with simulation experiments and to incorporate the findings in the experimental design. Subsequently, the model could be modified, such that the underlying mechanisms are disabled to investigate their impact (Bathmann et al. 2020, 2021). We hypothesize, that this approach would reveal the regimes, where specific feedbacks contribute to emerging ecosystem properties such as mangrove zonation. Additionally, ecosystem response to changing environmental conditions such as increased precipitation or periods of drought could be analysed by variation of the model setup according to predicted changes in environmental conditions. This includes, but is not limited to, cascading effects of single actions such as the installation of impoundments or the cutting of trees. This approach might even reveal yet unknown early warning signals for drastic ecosystem state changes (Scheffer et al. 2009) in mangroves such as mass tree mortality which has been observed in northern Australia (Duke et al. 2017; Lovelock et al. 2017).

Additionally, models can accommodate the investigation of complex interactions to focus on the implications of specific plant-soil feedbacks. Examples for a plant litter decomposition-nutrient availability feedback (Grueters et al. 2019) or a mechanistic plant water use-porewater salinity feedback (Bathmann et al. 2020) model are already available in the literature. Consequently, hypotheses on the mechanisms driving feedbacks derived from empirical findings could be tested using these numerical models. The combination of models and experiments allows assessment of the relative strength of different feedbacks, when multiple feedbacks are apparent in a system (Bathmann et al. 2020, 2021), which could further add to the knowledge of mangrove resilience in the face of environmental change.

\section{Conclusions}

The extent of the resilience of mangroves to climate change and other disturbances is important for the maintenance of ecosystem services that communities derive from mangroves. There is both empirical and theoretical evidence that plant-soil feedbacks play a crucial role in maintaining mangrove ecosystem stability. An enhanced understanding of the plant-soil feedbacks that underlie the stability of mangroves, as well as the characteristics that may indicate impending state transitions for mangroves will allow better prediction of the fate of mangroves in response to climate change and thus enhance the capacity to manage mangrove ecosystem dynamics in the future. Exploration of models that describe feedbacks between plants and soil elevation, porewater salinity and nutrient biogeochemistry will provide novel insights into mangrove ecosystem stability in the future.

Author contribution statement All authors contributed to the idea and the revision of the manuscript. JB and MCW performed the literature search and drafted the manuscript and thereby equally shared first-author responsibilities. CL, $\mathrm{JJ}, \mathrm{MW}, \mathrm{RP}$ and UB contributed to the discussion and revision of the manuscript.

Supplementary Information The online version contains supplementary material available at https://doi.org/10.1007/s00468-021-02182-z. 
Acknowledgements This study was financed by the TU Dresden by fellowships for CL and JJ in the frame of the Winter School MARZIPAN 2018. JB was financed by German Research Foundation (DFG, Project Number 398759560) and MCW was financed by the Volkswagen Foundation (Volkswagen Stiftung, Project Number 94 844).

Funding Open Access funding enabled and organized by Projekt DEAL. See acknowledgements.

Availability of data and material Not applicable.

Code availability Not applicable.

\section{Declarations}

Conflict of interest The authors declare that they have no conflict of interest.

Open Access This article is licensed under a Creative Commons Attribution 4.0 International License, which permits use, sharing, adaptation, distribution and reproduction in any medium or format, as long as you give appropriate credit to the original author(s) and the source, provide a link to the Creative Commons licence, and indicate if changes were made. The images or other third party material in this article are included in the article's Creative Commons licence, unless indicated otherwise in a credit line to the material. If material is not included in the article's Creative Commons licence and your intended use is not permitted by statutory regulation or exceeds the permitted use, you will need to obtain permission directly from the copyright holder. To view a copy of this licence, visit http://creativecommons.org/licenses/by/4.0/.

\section{References}

Akamatsu Y, Ikeda S (2016) Surface and subsurface water coupled ecological model in a mangrove swamp, Ishigaki Island, Japan. J Hydro-Environ Res 11:146-159. https://doi.org/10.1016/j.jher. 2015.03.005

Alongi DM (2008) Mangrove forests: Resilience, protection from tsunamis, and responses to global climate change. Estuar Coast Shelf Sci 76:1-13. https://doi.org/10.1016/j.ecss.2007.08.024

Alongi DM (2015) The impact of climate change on mangrove forests. Current climate change reports. Springer. https://doi.org/ 10.1007/s40641-015-0002-x

Alongi DM (2018) Impact of global change on nutrient dynamics in mangrove forests. Forests 9:596. https://doi.org/10.3390/f9100 596

Asbridge EF, Bartolo R, Finlayson CM, Lucas RM, Rogers K, Woodroffe CD (2019) Assessing the distribution and drivers of mangrove dieback in Kakadu National Park, northern Australia. Estuar Coast Shelf Sci 228:106353. https://doi.org/10.1016/j. ecss.2019.106353

Balke T, Herman PMJ, Bouma TJ (2014) Critical transitions in disturbance-driven ecosystems: identifying windows of opportunity for recovery. J Ecol 102:700-708. https://doi.org/10.1111/13652745.12241

Ball MC (1988) Salinity tolerance in the mangroves Aegiceras corniculatum and Avicennia marina. I. Water use in relation to growth, carbon partitioning, and salt balance. Aust J Plant Physiol 15:447-464. https://doi.org/10.1071/PP9880447

Ball MC, Pidsley SM (1995) Growth responses to salinity in relation to distribution of two mangrove species, Sonneratia alba and S. lanceolata, in Northern Australia. Funct Ecol 9:77-85. https:// doi.org/10.2307/2390093

Barbier EB, Georgiou IY, Enchelmeyer B, Reed DJ (2013) The value of wetlands in protecting southeast Louisiana from hurricane storm surges. PLoS ONE 8:e58715. https://doi.org/10.1371/journ al.pone.0058715

Bathmann J, Peters R, Naumov D, Fischer T, Berger U, Walther M (2020) The MANgrove-GroundwAter feedback model (MANGA) — describing belowground competition based on first principles. Ecol Model 420:108973. https://doi.org/10.1016/j. ecolmodel.2020.108973

Bathmann JTF, Peters R, Reef R, Berger U, Walther M, Lovelock CE (2021) Modelling mangrove forest structure and species composition over tidal inundation gradients: The feedback between plant water use and porewater salinity in an arid mangrove ecosystem. Agric For Meteorol (in press)

Bever JD, Westover KM, Antonovics J (1997) Incorporating the soil community into plant population dynamics: the utility of the feedback approach. J Ecol 85:561-573. https://doi.org/10.2307/ 2960528

Brunier G, Anthony EJ, Gratiot N, Gardel A (2019) Exceptional rates and mechanisms of muddy shoreline retreat following mangrove removal. Earth Surf Proc Land 44:1559-1571. https://doi.org/ 10.1002/esp.4593

Cahoon DR, Lynch JC (1997) Vertical accretion and shallow subsidence in a mangrove forest of southwestern Florida, USA. Mangrove Salt Marshes 1:173-186. https://doi.org/10.1023/A:10099 04816246

Cahoon DR, Hensel P, Rybczyk J, McKee KL, Proffitt CE, Perez BC (2003) Mass tree mortality leads to mangrove peat collapse at Bay Islands, Honduras after Hurricane Mitch. J Ecol 91:10931105. https://doi.org/10.1046/j.1365-2745.2003.00841.x

Cahoon DR, Hensel PF, Spencer T, Reed DJ, McKee KL, Saintilan N (2006) Coastal Wetland Vulnerability to Relative Sea-Level Rise: Wetland Elevation Trends and Process Controls. In: Verhoeven JT, Beltman B, Bobbink R, Whigham DF (eds) Wetlands and natural resource management ecological studies (analysis and synthesis), vol 190. Springer, Berlin Heidelberg. https://doi.org/ 10.1007/978-3-540-33187-2_12

Cahoon DR, Hensel P, Rybczyk JM, Perez BC (2002) Hurricane Mitch: impacts on mangrove sediment elevation dynamics and longterm mangrove sustainability. Environ Sci Facul Staff Publ 49. https://cedar.wwu.edu/esci_facpubs/49. Accessed 16 June 2020

Carpenter SR, Cole JJ, Pace ML, Batt R, Brock WA, Cline T, Coloso J, Hodgson JR, Kitchell JF, Seekell DA, Smith L, Weidel B (2011) Early warnings of regime shifts: a whole-ecosystem experiment. Sci (NY) 332:1079-1082. https://doi.org/10.1126/science.12036 72

Chapin FS, McFarland J, David McGuire A, Euskirchen ES, Ruess RW, Kielland K (2009) The changing global carbon cycle: Linking plant-soil carbon dynamics to global consequences. J Ecol 97:840-850. https://doi.org/10.1111/j.1365-2745.2009.01529.x

Chen R, Twilley RR (1999) A simulation model of organic matter and nutrient accumulation in mangrove wetland soils. Biogeochemistry 44:93-118. https://doi.org/10.1007/bf00993000

Chen M, Pollard D, Barron EJ, Chen M, Pollard D, Barron EJ (2004) Regional climate change in east Asia simulated by an interactive atmosphere-soil-vegetation model. J Clim 17:557-572. https:// doi.org/10.1175/1520-0442(2004)017\%3c0557:RCCIEA\%3e2.0. $\mathrm{CO} ; 2$

Chen Y, Chen G, Ye Y (2015) Coastal vegetation invasion increases greenhouse gas emission from wetland soils but also increases soil carbon accumulation. Sci Total Environ 526:19-28. https:// doi.org/10.1016/j.scitotenv.2015.04.077 
Cintron G, Lugo AE, Pool DJ, Morris G (1978) Mangroves of arid environments in Puerto Rico and adjacent islands. Biotropica 10:110. https://doi.org/10.2307/2388013

Clough BF (1984) Growth and salt balance of the mangroves Avicennia marina (Forsk.) Vierh. and Rhizophora stylosa Griff. in relation to salinity. Aust J Plant Physiol 11:419-430. https://doi.org/10. 1071/PP9840419

D’Alpaos A, Da Lio C, Marani M (2012) Biogeomorphology of tidal landforms: physical and biological processes shaping the tidal landscape. Ecohydrology 5:550-562. https://doi.org/10.1002/ eco. 279

Sternberg LSL, Teh SY, Ewe SML, Miralles-Wilhelm F, DeAngelis DL (2007) Competition between hardwood hammocks and mangroves. Ecosystems 10:648-660. https://doi.org/10.1007/ s10021-007-9050-y

De Long JR, Fry EL, Veen GF, Kardol P (2019) Why are plant-soil feedbacks so unpredictable, and what to do about it? Funct Ecol 33:118-128. https://doi.org/10.1111/1365-2435.13232

Donato DC, Kauffman JB, Murdiyarso D, Kurnianto S, Stidham M, Kanninen M (2011) Mangroves among the most carbon-rich forests in the tropics. Nat Geosci 4:293-297. https://doi.org/ 10.1038/ngeo 1123

Duke NC, Ball MC, Ellison JC (1998) Factors influencing biodiversity and distributional gradients in mangroves. Glob Ecol Biogeogr Lett 7:27-47. https://doi.org/10.2307/2997695

Duke NC, Kovacs JM, Griffiths AD, Preece L, Hill DJE, Van Oosterzee P, Mackenzie J, Morning HS, Burrows D (2017) Largescale dieback of mangroves in Australia's Gulf of Carpentaria: a severe ecosystem response, coincidental with an unusually extreme weather event. Mar Freshw Res 68:1816-1829. https:// doi.org/10.1071/MF16322

Ehrenfeld JG, Ravit B, Elgersma K (2005) Feedback in the plant-soil system. Annu Rev Environ Resour 30:75-115. https://doi.org/ 10.1146/annurev.energy.30.050504.144212

Ellison AM, Farnsworth EJ (1996) Anthropogenic disturbance of Caribbean mangrove ecosystems: past impact, present trends, and future predictions. Biotropica 28:549-565. https://doi.org/ $10.2307 / 2389096$

Fagherazzi S, Kirwan ML, Mudd SM, Guntenspergen GR, Temmerman S, D'Alpaos A, van de Koppel J, Rybczyk JM, Reyes E, Craft C, Clough J (2012) Numerical models of salt marsh evolution: ecological, geomorphic, and climatic factors. Rev Geophys 50:1-28. https://doi.org/10.1029/2011RG000359

Feller IC (1995) Effects of nutrient enrichment on growth and herbivory of dwarf red mangrove (Rhizophora Mangle). Ecol Monogr 65:477-505. https://doi.org/10.2307/2963499

Feller IC, McKee KL, Whigham DF, O’Neill JP (2003) Nitrogen vs. phosphorus limitation across an ecotonal gradient in a mangrove forest. Biogeochemistry 62:145-175. https://doi.org/10. 1023/A:1021166010892

Feller IC, Lovelock CE, Piou C (2009) Growth and nutrient conservation in Rhizophora mangle in response to fertilization along latitudinal and tidal gradients. Smithson Contrib Mar Sci 38:345-358

Feller IC, Lovelock CE, Berger U, McKee KL, Joye SB, Ball MC (2010) Biocomplexity in mangrove ecosystems. Ann Rev Mar Sci 2:395-417. https://doi.org/10.1146/annurev.marine. 010908.163809

Friess DA, Rogers K, Lovelock CE, Krauss KW, Hamilton SE, Lee SY, Lucas R, Primavera J, Rajkaran A, Shi S (2019) The state of the world's mangrove forests: past, present, and future. Annu Rev Environ Resour 44:89-115. https://doi.org/10.1146/ annurev-environ-101718-033302

Gbondo-Tugbawa SS, Driscoll CT, Aber JD, Likens GE (2001) Evaluation of an integrated biogeochemical model (PnET-BGC) at a northern hardwood forest ecosystem. Water Resour Res 37:1057-1070. https://doi.org/10.1029/2000WR900375

Gilman EL, Ellison J, Duke NC, Field C (2008) Threats to mangroves from climate change and adaptation options: a review. Aquat Bot 89:237-250. https://doi.org/10.1016/J.AQUABOT. 2007.12.009

Gleason SM, Ewel KC, Hue N (2003) Soil redox conditions and plantsoil relationships in a Micronesian mangrove forest. Estuarine Coast Shelf Sci 56:1065-1074. https://doi.org/10.1016/S02727714(02)00307-4

Grueters U, Seltmann CT, Schmidt H, Horn H, Pranchai A, Vovides AG, Peters R, Vogt J, Dahdouh-Guebas F, Berger U (2014) The mangrove forest dynamics model mesoFON. Ecol Model 291:28-41. https://doi.org/10.1016/j.ecolmodel.2014.07.014

Grueters U, Ibrahim MR, Satyanarayana B, Dahdouh-Guebas F (2019) Individual-based modeling of mangrove forest growth: MesoFON-recent calibration and future direction. Estuar Coast Shelf Sci 227:106302. https://doi.org/10.1016/j.ecss.2019.106302

Halpern BS, Silliman BR, Olden JD, Bruno JP, Bertness MD (2007) Incorporating positive interactions in aquatic restoration and conservation. Frontiers in Ecology and the Environment. John Wiley \& Sons Ltd. https://doi.org/10.1890/1540-9295(2007) 5[153:IPIIAR]2.0.CO;2

Hao G-Y, Jones TJ, Luton C, Zhang Y-J, Manzane E, Scholz FG, Bucci SJ, Cao K-F, Goldstein G (2009) Hydraulic redistribution in dwarf Rhizophora mangle trees driven by interstitial soil water salinity gradients: impacts on hydraulic architecture and gas exchange. Tree Physiol 29:697-705. https://doi.org/10.1093/ treephys/tpp005

Hayes MA, Jesse A, Welti N, Tabet B, Lockington D, Lovelock CE (2019) Groundwater enhances above-ground growth in mangroves. J Ecol 107:1120-1128. https://doi.org/10.1111/13652745.13105

Herbert DA, Rastetter EB, Shaver GR, Âgren GI (1999) Effects of plant growth characteristics on biogeochemistry and community composition in a changing climate. Ecosystems 2:367-382. https:// doi.org/10.1007/s100219900086

Hillebrand H, Donohue I, Harpole WS, Hodapp D, Kucera M, Lewandowska AM, Merder J, Montoya JM, Freund JA (2020) Thresholds for ecological responses to global change do not emerge from empirical data. Nat Ecol Evolut. https://doi.org/10.1038/ s41559-020-1256-9

Hurst T, Pope A, Quinn G (2015) Exposure mediates transitions between bare and vegetated states in temperate mangrove ecosystems. Mar Ecol Prog Ser 533:121-134. https://doi.org/10. 3354/meps11364

Huxham M, Kumara MP, Jayatissa LP, Krauss KW, Kairo J, Langat J, Mencuccini M, Skov MW, Kirui B (2010) Intra- and interspecific facilitation in mangroves may increase resilience to climate change threats. Philos Trans R Soc 365:2127-2135. https://doi. org/10.1098/rstb.2010.0094

Janssen RHH, Meinders MBJ, van Nes EH, Scheffer M (2008) Microscale vegetation-soil feedback boosts hysteresis in a regional vegetation-climate system. Glob Change Biol 14:1104-1112. https://doi.org/10.1111/j.1365-2486.2008.01540.x

Jiang J, DeAngelis DL (2013) Strong species-environment feedback shapes plant community assembly along environmental gradients. Ecol Evol. https://doi.org/10.1002/ece3.784

Kirui BYK, Kairo JG, Skov MW, Mencuccini M, Huxham M (2012) Effects of species richness, identity and environmental variables on growth in planted mangroves in Kenya. Mar Ecol Prog Ser 465:1-10. https://doi.org/10.3354/meps09999

Kirwan ML, Murray AB (2007) A coupled geomorphic and ecological model of tidal marsh evolution. Proc Natl Acad Sci USA 104:6118-6122. https://doi.org/10.1073/pnas.0700958104 
Kirwan ML, Murray AB, Boyd WS (2008) Temporary vegetation disturbance as an explanation for permanent loss of tidal wetlands. Geophys Res Lett 35:L05403. https://doi.org/10.1029/2007G L032681

Kirwan ML, Guntenspergen GR, D’Alpaos A, Morris JT, Mudd SM, Temmerman S (2010) Limits on the adaptability of coastal marshes to rising sea level. Geophys Res Lett 37:L23401. https:// doi.org/10.1029/2010GL045489

Kirwan ML, Walters DC, Reay WG, Carr JA (2016) Sea level driven marsh expansion in a coupled model of marsh erosion and migration. Geophys Res Lett 43:4366-4373. https://doi.org/10.1002/ 2016GL068507

Krauss KW, Doyle TW, Doyle TJ, Swarzenski CM, From AS, Day RH, Conner WH (2009) Water level observations in mangrove swamps during two hurricanes in Florida. Wetlands 29:142-149. https://doi.org/10.1672/07-232.1

Krauss KW, Mckee KL, Lovelock CE, Cahoon DR, Saintilan N, Reef $\mathrm{R}$, Chen L (2014) How mangrove forests adjust to rising sea level. New Phytol 202:19-34. https://doi.org/10.1111/nph.12605

Lago ME, Miralles-Wilhelm F, Mahmoudi M, Engel V (2010) Numerical modeling of the effects of water flow, sediment transport and vegetation growth on the spatiotemporal patterning of the ridge and slough landscape of the Everglades wetland. Adv Water Resour 33:1268-1278. https://doi.org/10.1016/J.ADVWATRES. 2010.07.009

Lang'at JKS, Kairo JG, Mencuccini M, Bouillon S, Skov MW, Waldron S, Huxham M (2014) Rapid losses of surface elevation following tree girdling and cutting in tropical mangroves. PLoS ONE 9:e107868. https://doi.org/10.1371/journal.pone.0107868

Lee SY, Hamilton S, Barbier EB, Primavera J, Lewis RR (2019) Better restoration policies are needed to conserve mangrove ecosystems. Nature ecology and evolution. Nature Publishing Group. https://doi.org/10.1038/s41559-019-0861-y

Lewis RR (2005) Ecological engineering for successful management and restoration of mangrove forests. Ecol Eng 24:403-418. https://doi.org/10.1016/J.ECOLENG.2004.10.003

Lewis RR, Milbrandt EC, Brown B, Krauss KW, Rovai AS, Beever JW, Flynn LL (2016) Stress in mangrove forests: early detection and preemptive rehabilitation are essential for future successful worldwide mangrove forest management. Mar Pollut Bull 109:764-771. https://doi.org/10.1016/j.marpolbul.2016.03.006

Lin G, Da Silveira L, Sternberg L (1992) Comparative study of water uptake and photosynthetic gas exchange between scrub and fringe red mangroves, Rhizophora mangle L. Oecologia 90:399_ 403. https://doi.org/10.1007/BF00317697

Liu L, Li F, Yang Q, Tam NFY, Liao W, Zan Q (2014) Long-term differences in annual litter production between alien (Sonneratia apetala) and native (Kandelia obovata) mangrove species in Futian, Shenzhen China. Marine Pollut Bull 85:747-753. https:// doi.org/10.1016/J.MARPOLBUL.2014.04.047

Liu B, Zhao W, Wen Z, Yang Y, Chang X, Yang Q, Meng Y, Liu C (2019) Mechanisms and feedbacks for evapotranspirationinduced salt accumulation and precipitation in an arid wetland of China. J Hydrol 568:403-415. https://doi.org/10.1016/J.JHYDR OL.2018.11.004

Lovelock CE, Feller IC (2003) Photosynthetic performance and resource utilization of two mangrove species coexisting in a hypersaline scrub forest. Oecologia 134:455-462. https://doi. org/10.1007/s00442-002-1118-y

Lovelock CE, Feller IC, Mckee KL, Engelbrecht BMJ, Ball MC (2004) The effect of nutrient enrichment on growth, photosynthesis and hydraulic conductance of dwarf mangroves in Panamá. Funct Ecol 18:25-33. https://doi.org/10.1046/j.0269-8463.2004. 00805.x
Lovelock CE, Ball MC, Martin KC, Feller IC (2009) Nutrient enrichment increases mortality of mangroves. PLoS ONE 4:e5600. https://doi.org/10.1371/journal.pone.0005600

Lovelock CE, Cahoon DR, Friess DA, Guntenspergen GR, Krauss KW, Reef R, Rogers K, Saunders ML, Sidik F, Swales A, Saintilan N, Thuyen LX, Triet T (2015) The vulnerability of Indo-Pacific mangrove forests to sea-level rise. Nature 526:559-563. https:// doi.org/10.1038/nature15538

Lovelock CE, Feller IC, Reef R, Hickey S, Ball MC (2017) Mangrove dieback during fluctuating sea levels. Sci Rep 7:1680. https://doi. org/10.1038/s41598-017-01927-6

Lugo AE (1980) Mangrove Ecosystems: successional or steady state? Biotropica 12:65. https://doi.org/10.2307/2388158

May RM (1977) Thresholds and breakpoints in ecosystems with a multiplicity of stable states. Nature 269:471-477. https://doi.org/10. 1038/269471a0

Mazda Y, Magi M, Nanao H, Kogo M, Miyagi T, Kanazawa N, Kobashi D (2002) Coastal erosion due to long-term human impact on mangrove forests. Wetlands Ecol Manage 10(10):1-9. https://doi.org/10.1023/A:1014343017416

McIvor AL, Spencer T, Möller I, Spalding MD (2013) The response of mangrove soil surface elevation to sea level rise. In: Natural coastal protection series: report 3. Cambridge Coastal Research Unit Working Paper 42. Published by The Nature Conservancy and Wetlands International, pp 59 . ISSN 2050-7941. https:// www.conservationgateway.org/ConservationPractices/Marine/ crr/library/Documents/mangrove-surface-elevation-and-sealevel-rise.pdf. Accessed 19 July 2021

McKee KL (1993) Soil physicochemical patterns and mangrove species distribution-reciprocal effects? J Ecol 81:477. https://doi. org/10.2307/2261526

McKee KL (2011) Biophysical controls on accretion and elevation change in Caribbean mangrove ecosystems. Estuar Coast Shelf Sci 91:475-483. https://doi.org/10.1016/J.ECSS.2010.05.001

McKee KL, Cahoon DR, Feller IC (2007) Caribbean mangroves adjust to rising sea level through biotic controls on change in soil elevation. Glob Ecol Biogeogr 16:545-556. https://doi.org/ 10.1111/j.1466-8238.2007.00317.x

McKee KL, Rogers K, Saintilan N (2012) Response of salt marsh and mangrove wetlands to changes in atmospheric $\mathrm{CO}_{2}$, climate, and sea level. In: Global change and the function and distribution of wetlands. Springer, Dordrecht. https://doi.org/10.1007/ 978-94-007-4494-3_2

Mcleod E, Chmura GL, Bouillon S, Salm R, Björk M, Duarte CM, Lovelock CE, Schlesinger WH, Silliman BR (2011) A blueprint for blue carbon: toward an improved understanding of the role of vegetated coastal habitats in sequestering $\mathrm{CO}_{2}$. Front Ecol Environ 9:552-560. https://doi.org/10.1890/110004

Miki T, Kondoh M (2002) Feedbacks between nutrient cycling and vegetation predict plant species coexistence and invasion. Ecol Lett 5:624-633. https://doi.org/10.1046/j.1461-0248.2002. 00347.x

Miki T, Ushio M, Fukui S, Kondoh M (2010) Functional diversity of microbial decomposers facilitates plant coexistence in a plantmicrobe-soil feedback model. Proc Natl Acad Sci 107:1425114256. https://doi.org/10.1073/pnas.0914281107

Morris JT, Sundareshwar PV, Nietch CT, Kjerfve B, Cahoon DR (2002) Responses of coastal wetlands to rising sea level. Ecology 83:2869-2877. https://doi.org/10.1890/0012-9658(2002) 083[2869:ROCWTR]2.0.CO;2

Morris JT, Langley JA, Feller IC, Vervaeke WC, Hester MW, Chapman S, Morris JT, Langley JA, Feller IC, Vervaeke WC, Hester MW, Chapman S (2019) A model of the success of mangrove colonization at its northeastern boundary in Florida (USA) and Persistence in the Face of Rising Sea Level. AGUFM, EP11E-2084. 
https://ui.adsabs.harvard.edu/abs/2019AGUFMEP11E2084M/. Accessed 27 October 2020

Mudd SM, Howell SM, Morris JT (2009) Impact of dynamic feedbacks between sedimentation, sea-level rise, and biomass production on near-surface marsh stratigraphy and carbon accumulation. Estuar Coast Shelf Sci 82:377-389. https://doi.org/10.1016/j. ecss.2009.01.028

Naidoo G (2006) Factors contributing to dwarfing in the mangrove Avicennia marina. Ann Bot 97:1095-1101. https://doi.org/10. 1093/aob/mcl064

Nickerson NH, Thibodeau FR (1985) Association between pore water sulfide concentrations and the distribution of mangroves. Biogeochemistry 1:183-192. https://doi.org/10.1007/BF02185041

Noy-Meir I (1975) Stability of grazing systems: an application of predator-prey graphs. J Ecol 63:459. https://doi.org/10.2307/2258730

Oxford University Press (2020) Feedback. https://www.lexico.com/ definition/feedback. Accessed 20 Aug 2020

Passioura JB, Ball MC, Knight JH (1992) Mangroves may salinize the soil and in so doing limit their transpiration rate. Funct Ecol 6:476-481. https://doi.org/10.2307/2389286

Pernilla Brinkman E, Van der Putten WH, Bakker E-J, Verhoeven KJF (2010) Plant-soil feedback: experimental approaches, statistical analyses and ecological interpretations. J Ecol 98:1063-1073. https://doi.org/10.1111/j.1365-2745.2010. 01695.x

Peters R, Vovides AG, Luna S, Grüters U, Berger U (2014) Changes in allometric relations of mangrove trees due to resource availability - a new mechanistic modelling approach. Ecol Model 283:53-61. https://doi.org/10.1016/J.ECOLMODEL.2014.04. 001

Peters R, Walther M, Lovelock C, Jiang J, Berger U (2020) The interplay between vegetation and water in mangroves: new perspectives for mangrove stand modelling and ecological research. Wetlands Ecol Manage. https://doi.org/10.1007/s11273-020-09733-0

Polidoro BA, Carpenter KE, Collins L, Duke NC, Ellison AM, Ellison JC, Farnsworth EJ, Fernando ES, Kathiresan K, Koedam NE, Livingstone SR, Miyagi T, Moore GE, Ngoc Nam V, Ong JE, Primavera JH, Salmo SG, Sanciangco JC, Sukardjo S, Wang Y, Yong JWH (2010) The loss of species: mangrove extinction risk and geographic areas of global concern. PLoS ONE 5:e10095. https://doi.org/10.1371/journal.pone.0010095

Pugnaire FI, Morillo JA, Peñuelas J, Reich PB, Bardgett RD, Gaxiola A, Wardle DA, Van Der Putten WH (2019) Climate change effects on plant-soil feedbacks and consequences for biodiversity and functioning of terrestrial ecosystems. Sci Adv Am Assoc Adv Sci. https://doi.org/10.1126/sciadv.aaz1834

Putten WH, Bradford MA, Brinkman EP, Voorde TFJ, Veen GF (2016) Where, when and how plant-soil feedback matters in a changing world. Funct Ecol 30:1109-1121. https://doi.org/10.1111/ $1365-2435.12657$

Ramaprasad A (1983) On the definition of feedback. Behav Sci 28:4 13. https://doi.org/10.1002/bs.3830280103

Renzi JJ, He Q, Silliman BR (2019) Harnessing positive species interactions to enhance coastal wetland restoration. Frontiers in ecology and evolution. Front Media S.a. https://doi.org/10.3389/fevo. 2019.00131

Rietkerk M, van de Koppel J (1997) Alternate stable states and threshold effects in semi-arid grazing systems. Nordic Soc Oikos 79:69-76. https://doi.org/10.2307/3546091

Rietkerk M, van de Koppel J (2008) Regular pattern formation in real ecosystems. Trends Ecol Evol 23:169-175. https://doi.org/10. 1016/J.TREE.2007.10.013

Rietkerk M, Dekker SC, de Ruiter PC, van de Koppel J (2004) Selforganized patchiness and catastrophic shifts in ecosystems. Sci (NY) 305:1926-1929. https://doi.org/10.1126/science.1101867
Röderstein M, Perdomo L, Villamil C, Hauffe T, Schnetter ML (2014) Long-term vegetation changes in a tropical coastal lagoon system after interventions in the hydrological conditions. Aquat Bot 113:19-31. https://doi.org/10.1016/j.aquabot.2013.10.008

Rogers K, Kelleway JJ, Saintilan N, Megonigal JP, Adams JB, Holmquist JR, Lu M, Schile-Beers L, Zawadzki A, Mazumder D, Woodroffe CD (2019) Wetland carbon storage controlled by millennial-scale variation in relative sea-level rise. Nature 567:91-95. https://doi.org/10.1038/s41586-019-0951-7

Rybczyk JM, Callaway JC, Day JW (1998) A relative elevation model for a subsiding coastal forested wetland receiving wastewater effluent. Ecol Model 112:23-44. https://doi.org/10.1016/S03043800(98)00125-2

Saintilan N, Khan NS, Ashe E, Kelleway JJ, Rogers K, Woodroffe CD, Horton BP (2020) Thresholds of mangrove survival under rapid sea level rise. Science 368:1118-1121. https://doi.org/10.1126/ science.aba2656

Sánchez-Núñez DA, Bernal G, Mancera Pineda JE (2019) The relative role of mangroves on wave erosion mitigation and sediment properties. Estuaries Coasts. https://doi.org/10.1007/ s12237-019-00628-9

Sasmito SD, Murdiyarso D, Friess DA, Kurnianto S (2016) Can mangroves keep pace with contemporary sea level rise? A global data review. Wetlands Ecol Manage 24:263-278. https://doi.org/10. 1007/s11273-015-9466-7

Scheffer M, Carpenter SR (2003) Catastrophic regime shifts in ecosystems: linking theory to observation. Trends Ecol Evol 18:648656. https://doi.org/10.1016/J.TREE.2003.09.002

Scheffer M, Carpenter S, Foley JA, Folke C, Walker B (2001) Catastrophic shifts in ecosystems. Nature 413:591-596. https://doi. org/10.1038/35098000

Scheffer M, Bascompte J, Brock WA, Brovkin V, Carpenter SR, Dakos V, Held H, van Nes EH, Rietkerk M, Sugihara G (2009) Earlywarning signals for critical transitions. Nature 461:53-59. https:// doi.org/10.1038/nature08227

Schuerch M, Spencer T, Temmerman S, Kirwan ML, Wolff C, Lincke D, McOwen CJ, Pickering MD, Reef R, Vafeidis AT, Hinkel J, Nicholls RJ, Brown S (2018) Future response of global coastal wetlands to sea-level rise. Nature 561:231-234. https://doi.org/ 10.1038/s41586-018-0476-5

Sherman RE, Fahey TJ, Howarth RW (1998) Soil-plant interactions in a neotropical mangrove forest: iron, phosphorus and sulfur dynamics. Oecologia 115:553-563. https://doi.org/10.1007/ s004420050553

Sherman RE, Fahey TJ, Martinez P (2003) Spatial patterns of biomass and aboveground net primary productivity in a mangrove ecosystem in the Dominican Republic. Ecosystems 6:384-398. https:// doi.org/10.1007/s10021-002-0191-8

Silvestri S, Defina A, Marani M (2005) Tidal regime, salinity and salt marsh plant zonation. Estuar Coast Shelf Sci 62:119-130. https:// doi.org/10.1016/J.ECSS.2004.08.010

Smoak JM, Breithaupt JL, Smith TJ, Sanders CJ (2013) Sediment accretion and organic carbon burial relative to sea-level rise and storm events in two mangrove forests in Everglades National Park. CATENA 104:58-66. https://doi.org/10.1016/J.CATENA. 2012.10.009

Spalding M, Kainuma M, Collins L (2010) World atlas of mangroves. Earthscan, London, p 319 (ISBN: 978-1-84407-657-4)

Suding KN, Gross KL, Houseman GR (2004) Alternative states and positive feedbacks in restoration ecology. Trends in ecology and evolution. Elsevier. https://doi.org/10.1016/j.tree.2003.10.005

Swanson KM, Drexler JZ, Schoellhamer DH, Thorne KM, Casazza ML, Overton CT, Callaway JC, Takekawa JY (2014) Wetland accretion rate model of ecosystem resilience (WARMER) and Its application to habitat sustainability for endangered species in the 
San Francisco estuary. Estuaries Coasts 37:476-492. https://doi. org/10.1007/s12237-013-9694-0

Teh SY, DeAngelis DL, da Sternberg LSL, Miralles-Wilhelm FR, Smith TJ, Koh H-L (2008) A simulation model for projecting changes in salinity concentrations and species dominance in the coastal margin habitats of the Everglades. Ecol Model 213:245256. https://doi.org/10.1016/J.ECOLMODEL.2007.12.007

Teh SY, Koh HL, DeAngelis DL, Turtora M (2013) Interaction between salinity intrusion and vegetation succession: a modeling approach. Theor Appl Mech Lett 3:032001. https://doi.org/10. 1063/2.1303201

Teh SY, Turtora M, DeAngelis D, Jiang J, Pearlstine L, Smith T, Koh $\mathrm{H}$ (2015) Application of a coupled vegetation competition and groundwater simulation model to study effects of sea level rise and storm surges on coastal vegetation. J Marine Sci Eng. https:// doi.org/10.3390/jmse3041149

Tilman D (1987) Secondary succession and the pattern of plant dominance along experimental nitrogen gradients. Ecol Monogr 57:189-214. https://doi.org/10.2307/2937080

Twilley R, Day J, Bevington A, Castañeda-Moya E, Christensen A, Holm G, Heffner L, Lane R, McCall A, Aarons A, Li S, Freeman A, Rovai A (2019) Ecogeomorphology of coastal deltaic floodplains and estuaries in an active delta: insights from the Atchafalaya Coastal Basin. Estuar Coast Shelf Sci 227:106341. https://doi.org/10.1016/j.ecss.2019.106341

Valiela I, Cole ML (2002) Comparative evidence that salt marshes and mangroves may protect seagrass meadows from land-derived nitrogen loads. Ecosystems 5:92-102. https://doi.org/10.1007/ s10021-001-0058-4

Valiela I, Foreman K, LaMontagne M, Hersh D, Costa J, Peckol P, DeMeo-Andreson B, D'Avanzo C, Babione M, Sham C-H, Brawley J, Lajtha K (1992) Couplings of watersheds and coastal waters: sources and consequences of nutrient enrichment in Waquoit Bay. Massachusetts Estuaries 15:443. https://doi.org/ $10.2307 / 1352389$

Vitousek PM, Aber JD, Howarth RW, Likens GE, Matson PA, Schindler DW, Schlesinger WH, Tilman DG (1997) Human alteration of the global nitrogen cycle: sources and consequences. Ecol Appl 7:737-750. https://doi.org/10.1890/1051-0761(1997) 007[0737:HAOTGN]2.0.CO;2
Walters BB, Rönnbäck P, Kovacs JM, Crona B, Hussain SA, Badola R, Primavera JH, Barbier EB (2008) Ethnobiology, socio-economics and management of mangrove forests: a review. Aquat Bot 89:220-236. https://doi.org/10.1016/J.AQUABOT.2008.02.009

Wang H, Hsieh YP, Harwell MA, Huang W (2007) Modeling soil salinity distribution along topographic gradients in tidal salt marshes in Atlantic and Gulf coastal regions. Ecol Model 201:429-439. https://doi.org/10.1016/j.ecolmodel.2006.10.013

Whitt AA, Coleman R, Lovelock CE, Gillies C, Ierodiaconou D, Liyanapathirana M, Macreadie PI (2020) March of the mangroves: drivers of encroachment into southern temperate saltmarsh. Estuar Coast Shelf Sci. https://doi.org/10.1016/j.ecss. 2020.106776

Woodroffe CD, Rogers K, Mckee KL, Lovelock CE, Mendelssohn IA, Saintilan N (2016) Mangrove sedimentation and response to relative sea-level rise. Annu Rev Mar Sci 8:243-266. https://doi.org/ 10.1146/annurev-marine-122414-034025

Xiao S, Atwater DZ, Callaway RM (2019) Integrating spatial structure and interspecific and intraspecific plant-soil feedback effects and responses into community structure. Oikos. https://doi.org/10. 1111/oik.05915

Yando ES, Osland MJ, Jones SF, Hester MW (2019) Jump-starting coastal wetland restoration: a comparison of marsh and mangrove foundation species. Restor Ecol 27:1145-1154. https://doi.org/ 10.1111/rec. 12963

Zeng C, Wang H (2012) Noise and large time delay: accelerated catastrophic regime shifts in ecosystems. Ecol Model 233:52-58. https://doi.org/10.1016/J.ECOLMODEL.2012.03.025

Zhang Y, Li W, Sun G, Miao G, Noormets A, Emanuel R, King JS (2018) Understanding coastal wetland hydrology with a new regional-scale, process-based hydrological model. Hydrol Process 32(20):3158-3173. https://doi.org/10.1002/hyp.13247

Publisher's Note Springer Nature remains neutral with regard to jurisdictional claims in published maps and institutional affiliations. 